\title{
Evaluation of healing prosthetic materials polyester mesh resorbable film and collagen elastin matrix /polypropylene used in rabbits abdominal wall defects ${ }^{1}$
}

\author{
Avaliação da cicatrização da tela de poliéster com lâmina absorvível e a tela de \\ colágeno-elastina/polipropileno utilizadas no reparo de lesões da parede abdominal de coelhos
}

\author{
Danielle Duck SchulzI, Nicolau Gregori Czeczko", Osvado MalafaiaII, Gustavo Justo Schulz', Leticia Elizabeth A. Czeczko" ${ }^{\text {III }}$ \\ Larissa Santin Garcia ${ }^{\text {III, }}$ Ulrich Andreas Dietz ${ }^{\text {II }}$ \\ ${ }^{\mathrm{I}}$ Master, Principles of Surgery Post-Graduate Program, Evangelical Medical School, Curitiba-PR, Brazil. \\ ${ }^{\text {II }} \mathrm{PhD}$, Full Professor, Post-Graduate Program, Evangelical Medical School, Curitiba-PR, Brazil. \\ ${ }^{\text {III }}$ Medical student, Evangelical Faculty of Parana, Curitiba-PR, Brazil.
}

\begin{abstract}
Purpose: To compare polyester with absorbable layer prosthesis with collagen-elastin/polypropylene prosthesis in the repair of abdominal wall defects. Methods: The 16 studied rabbits were divided in groups A and B (euthanized on the 30th and 60th days, after the implant of the mesh). The animals underwent laparotomy and received a $2 \mathrm{~cm}$ wall "defect" on each side of the Alba linea. The repair was made with the suture of a polyester mesh with absorbable film on the left side of the Alba Linea and with collagen-elastin/ polypropylene mesh on the right side. Adherences were classified according to Nair Score and microscopic evaluation observing types I and III collagen formation and other immunohistochemical analyses. Results: There were no significant differences in adhesion formation. The collagen type I showed higher deposition in polyester with absorbable layer. In group B, the difference between the meshes was significant, with higher collagen III deposition in polyester with absorbable layer (60 ${ }^{\circ}$ P.O.). About the metalloproteinases, the presence of MMP -1 and MMP-8 were about the same; the expression of MMP-13 increased near to the 60 th day. Conclusions: There is no significant difference between the two meshes in adhesion formation and immunohystochemical evaluation. The polyester mesh resorbable film presented a higher deposition of collagen.

Key words: Surgical Mesh. Hernia. Immunohistochemistry. Rabitts.
\end{abstract}

\section{RESUMO}

Objetivo: Comparar a tela poliéster com lâmina absorvível e a confeccionada pela aposição da tela de colágeno-elastina/polipropileno no reparo de lesões da parede abdominal. Métodos: Foram avaliados 16 coelhos, divididos aleatoriamente em dois grupos e submetidos a eutanásia no $30^{\circ}$ e no $60^{\circ}$ dia P.O. Os animais foram submetidos à laparotomia e confecção de dois defeitos triangulares de $2 \mathrm{~cm}$, de espessura total, na parede abdominal ventral. A correção foi realizada através de fixação, na metade esquerda da linha alba, da tela de poliéster com lâmina absorvível e na direita, tela composta por colágeno-elastina/polipropileno. As aderências foram classificadas conforme o escore de Nair e a avaliação microscópica incluiu avaliação do colágeno (tipos I e III) e imunoistoquímica. Resultados: Não houve diferença quanto à formação de aderências. O colágeno tipo I apresentou maior concentração com a tela Poliéster com lâmina absorvível. No grupo B foi encontrada diferença significativa entre as telas, com aumento do colágeno tipo III com a tela Poliéster com lâmina absorvível (60 P.O.). A avaliação das metaloproteinases MMP-1 e MMP-8 não apresentaram diferença significativa; a MMP-13 apresentou aumento significativo na imunoexpressão no $60^{\circ}$ P.O. Conclusões: Não há diferença significativa entre as telas quanto às aderências e avaliação imunoistoquímica. A tela de poliéster com lâmina absorvível apresenta maior formação de colágeno.

Descritores: Telas Cirúrgicas. Hérnia. Imunoistoquímica. Coelhos.

${ }^{1}$ Research performed at Institute of Medical Research, Post-Graduate Program in Principles of Surgery, Curitiba Evangelic University Hospital Evangelical School of Parana, Curitiba-PR, Brazil. 


\section{Introduction}

Incisional hernias occur, approximately, in $11 \%$ of laparotomies $^{1}$ and are responsible for an important part of co-morbidity associated with surgical treatment, causing considerable socioeconomic impact. The surgical repair of incisional hernias with the use of meshes is an interesting alternative because it makes the suturing of the abdominal cavity possible without tensioning the tissues and decreasing the rate of recurrence that may reach $40 \%$ of the cases, when only the primary repair is done ${ }^{3}$. However, the use of prosthetic material to repair incisional hernias is not free of complications, especially when the use of intra-peritoneal mesh is necessary. When we place organs in direct contact with prostheses, an intense inflammatory response occurs with adherence formation, related to intestinal occlusions ${ }^{4}$, fistulas ${ }^{5}$ and chronic abdominal pain.

Many kinds of meshes have been tested aiming at guarantying low adherence formation and the possibility of adequately treating major hernia defects. After polypropylene, polytetrafluorethylene polyester ${ }^{6}$, polyglactin, silicone, human dura-mater and hiyaluronate ${ }^{6,7}$ have been used. None of these materials alone can be considered "golden-standard" in hernia repair; in other words, all of them present some disadvantages and complications related to their use.

In search of the ideal mesh, many different material combinations have been studied to guarantee low adherence formation, resistance and good cicatrization. This work aims at comparatively evaluating two new mesh types: the polyester mesh with absorbable layer and the collagen-elastin/polypropylene mesh, to repair abdominal wall lesions in rabbits, analyzing post-operatory peritoneal adherence formation, collagen formation and metalloproteinase immunoexpression involved in the cicatrization process.

\section{Methods}

The research was approved by the Ethics Committee in Research of the Beneficent Evangelic Society.

Sixteen female adult rabbits (Oryctolagus cuniculus) were studied, weighing an average $3 \mathrm{~kg}$. The animals were randomly divided in two groups: group A to be euthanized 30 days after the surgery and group B on the 60th day after surgery. Each animal served as control of itself.

The animals were kept in cages at the animal colony of the Institute of Medical Research and received adequate rabbit food and free access to water. The animals were kept at 12 hours day/night cycle, at $24^{\circ} \mathrm{C}$ room temperature.

Each animal was anesthetized with a mixture of Ketamine chlroridrate $(50 \mathrm{mg} / \mathrm{kg})$ and xylazine $(70 \mathrm{mg} / \mathrm{kg})$, intramuscularly administered $^{12}$. After anesthesia, the animals received a unique preventive intravenous dose of antibiotics (Cefazolin 0, $125 \mathrm{mg} / \mathrm{kg}$ ).

Two meshes were used in the experiment: the first one, a polyester mesh with absorbable film was industrially produced with two faces, one of polyester and the other one of anti-adhesive collagen re-absorbable film with quick tissue integration and inhibition of visceral adherences; the other one was a handicrafted product made with apposition and fixation by suturing the collagen-elastin mesh to the polypropylene mesh. The collagenelastin mesh is a tridimensional matrix composed of native structurally intact collagen fibers and elastin, developed to support dermal regeneration. Its collagen was obtained from bovine dermis that contains types I, II, III and IV dermal collagen. Elastin is obtained from the bovine nuchal ligament by hydrolysis. To repair the defects, $3 \times 4 \mathrm{~cm}$ rectangular flaps were made for both meshes.

The surgical procedure, after the shaving of the animals' back and cutaneous sterilization, proceeded with a median ventral longitudinal incision of approximately $5 \mathrm{~cm}$, involving the skin and the subcutaneous tissue. Next, the subcutaneous cellular tissue was lifted and the muscular plane of the abdominal wall was exposed through rhombic dissection to cause a double lesion to the right and left of the linea Alba. The effect to be created was standardized with an equilateral triangle mold (2 $\mathrm{cm}$ on its side) that should interest the whole thickness of the muscular wall and the peritoneum. On these defects, to the left of the linea Alba, polyester flaps with absorbable film were sutured, with its film face placed with visceral contact. The collagen-elastin/ polypropylene mesh was implanted to the right with its collagenelastin face with visceral contact. The fixation of the meshes with their respective defects was made with simple 3.0 polypropylene stitches. The continuous suturing of the skin with 4.0 nylon thread and a homeostasis revision ended the surgical procedure.

After the surgery, the animals were followed up until they completely recovered from anesthesia. An intra-muscular dose of analgesic (dypirona $25 \mathrm{mg} / \mathrm{kg}$ ) was administered to the animals kept in cages with free access to water and appropriate animal food, for four hours after surgery. Post-operatory follow up was done daily, checking food ingestion, motility and complications on the surgical wound.

On the 30th day after surgery, eight animals were randomly selected and euthanized (group I). The rest of the animals were anesthetized and were administered 1\% KCI 19.

After the animals' death, they were placed on dorsal position for the inspection of the presence of infection on the surgical wound, for tissue collections on sub-cutaneuos tissue and suture integrity. Next, a new laparotomy was performed with a hypogastric incision, on each extremity, in the direction of the right and left flanks, thus exposing the whole ventral abdominal wall. Next, there was an inspection of the peritoneal cavity with the evaluation of adherences according to the classification of Nair et al. ${ }^{1}$ (Chart 1). Next, the surgical piece containing the whole experimentation area was cut with the structures and organs removed in monoblocks. The pieces were fixed on cardboard molds so that they did not retract inside the formaldehyde flasks and the position of the pieces was identified (right side/left side of the abdominal wall). The $10 \%$ formaldehyde flasks were sent for microscopic analysis. 
CHART 1 - NAIR's adhesion score

\begin{tabular}{|c|l|}
\hline Score & Description \\
\hline 0 & No adherence \\
\hline I & Single adherence between two organs or between an organ and the abdominal wall \\
\hline II & Two adherences between organs or one organ and the abdominal wall \\
\hline III & $\begin{array}{l}\text { More than two adherences between the organs or a massive generalized adherence of the } \\
\text { intestine with no adherence to the abdominal wall. }\end{array}$ \\
\hline IV & $\begin{array}{l}\text { Generalized adherences between organs and the abdominal wall or massive adherence } \\
\text { among all organs }\end{array}$ \\
\hline
\end{tabular}

The mounting of glass slides for histological analysis as well as the interpretation of the results were made at the University of Würzburg, Germany.

Picrosirius-red staining was used for collagen study. For the immunochemical analysis MMP-1, MMP-9 and MMP-13 antibodies were studied, all of them related to collagenases involved with collagen catabolism. The interpretation of the immunochemical analysis was made with 5.1 ImagePro-Plus.

Average values, standard deviation, medians, 95\% trust intervals were calculated as well as minimum and maximum values. The comparison of the values among groups and subgroups with the Turkey-Kramer test for multiple comparisons (ANOVA) was also done. Statistical tests were made with the GraphPad InStat 3.1 and StatMet. For group comparison, considering each mesh, Mann-Whitney non-parametric test and Fisher's exact test were used. For mesh comparison, in each group, the non-parametric Wilcoxon test and the binomial test were used. $\mathrm{p}<0,05$ values indicated statistic significance.

\section{Results}

There were no complications during surgery and all the animals presented normal post-anesthetic recovery. In the course of daily clinical evaluation, 13 animals presented good recovery, with normal physical activity and normal appetite. In group A, animals numbered 7 an 8 died and necropsy indicated no apparent cause. Animal 8 in group B died on the 9th day of post-operatory period. Necropsy showed the distention of the intestinal loops and a few adherences.

Animal 2 of group A presented important ulceration on the surgical wound. The rest of the animals of the same group were in good physical condition and presented favorable evolution of the surgical wound.

Only one animal of group B presented erosion of the surgical wound on the same side of the polyester with absorbable film mesh implant. All the other animals presented good cicatrization.

None of the groups presented hernial recidivism neither with the polyester mesh with absorbable film nor with the collagenelastin/polypropylene mesh. None of the animals in both groups presented signs of infection or fistulas.

As to intra-peritoneal adherences, the results did not present statistic significance in group A (Table 1). Most adherences were classified as Nair 1 and involved the greatest omentum, 28,6\% of the animals with polyester with absorbable film mesh and the large intestine in $50 \%$ of the animals with collagen-elastin/ polypropylene mesh.

TABLE 1 - Intra-peritoneal adherences - NAIR's classification

\begin{tabular}{cccc}
\hline Group & $\begin{array}{c}\text { NAIR's Classification - } \\
\text { Score }\end{array}$ & $\begin{array}{c}\text { Polyester with } \\
\text { absorbable film }\end{array}$ & $\begin{array}{c}\text { Collagen - } \\
\text { elastin/polypropylene }\end{array}$ \\
\hline A & 0 & 1 & 1 \\
& I & 4 & 4 \\
& II & 1 & 1 \\
& III & 0 & 0 \\
\hline B & 0 & 4 & 1 \\
& I & 3 & 4 \\
& II & 0 & 2 \\
& III & 0 & 0 \\
\hline
\end{tabular}


There was no statistic difference in the evaluation of group B adherences, although on the collagen-elastin/polypropylene mesh 2 animals presented score II classification and the polyester with absorbable mesh did not present adherences in 4 animals. Organ adherence in group B presented the highest omentum, in $28,6 \%$ of the cases on the polyester with absorbable film and the large intestine, in 57\% of the animals with collagen-elastin/ polypropylene mesh.

Statistic tests indicate that in group A there was a significant statistic difference $(p=0,046)$ with greater concentration of type I collagen in polyester with absorbable film mesh (Figure 1). Group B did not present significant difference although the polyester with absorbable film mesh presented greater collagen concentration than collagen-elastin/polypropylene mesh.

Comparing Groups A and $\mathrm{B}$ in relation to the polyester mesh with absorbable film, there was significant difference $(p=0,008)$ which means greater collagen concentration on the first 30 days, however, on the 60th day of the post-operatory period this concentration declined. According to the results obtained, there was no significant difference for the collagen-elastin/polypropylene mesh but collagen concentration declined on the 60 th day of post-operatory period.

As to collagen III, there was no statistic difference between the two kinds of mesh in group A. In group $\mathrm{B}$ there was a significant difference between the meshes $(p=0,028)$ because there was a considerable increase in type III collagen with the polyester mesh with absorbable film on the 60th day. However, this type III collagen concentration was not significant in the isolated evaluation between groups A and B (Figure 2).

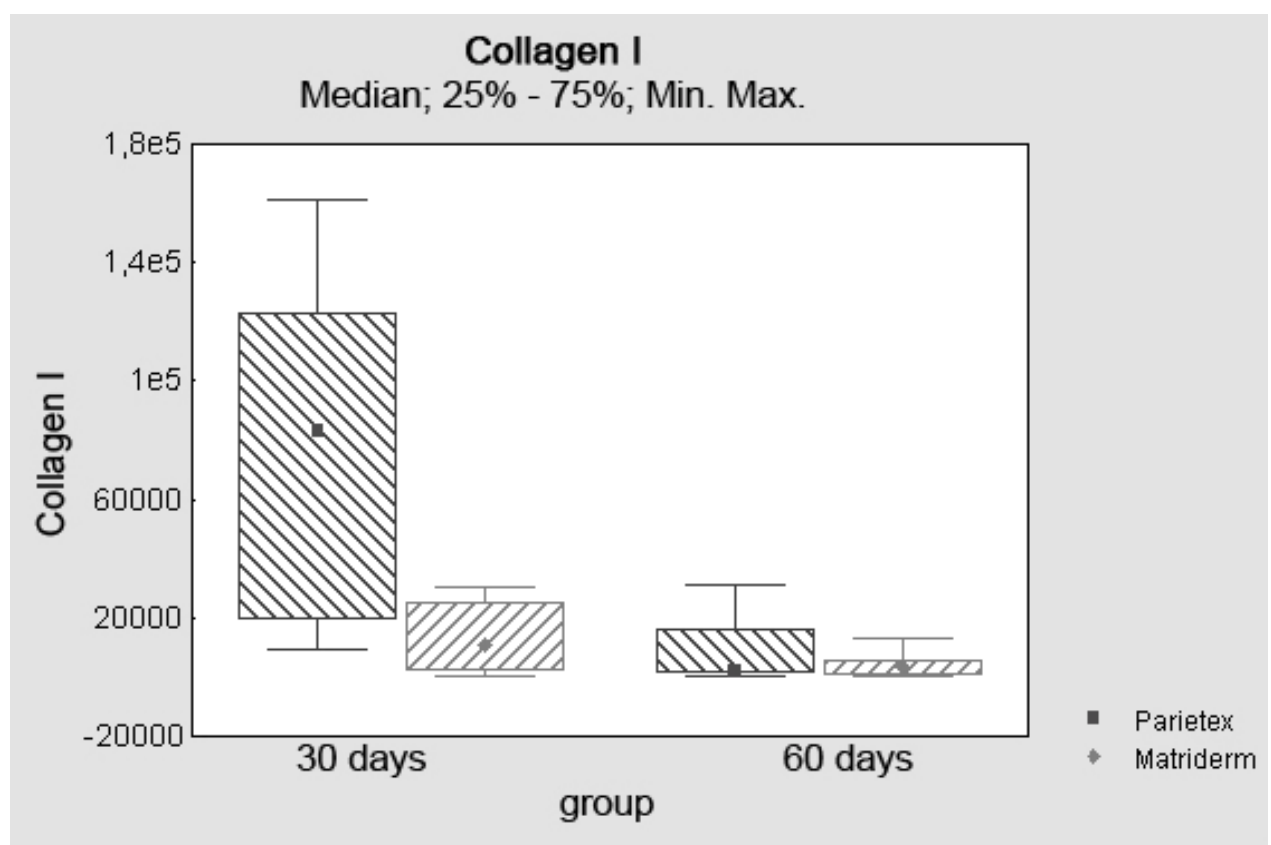

FIGURE 1 - Type I Collagen evaluation on the studied meshes

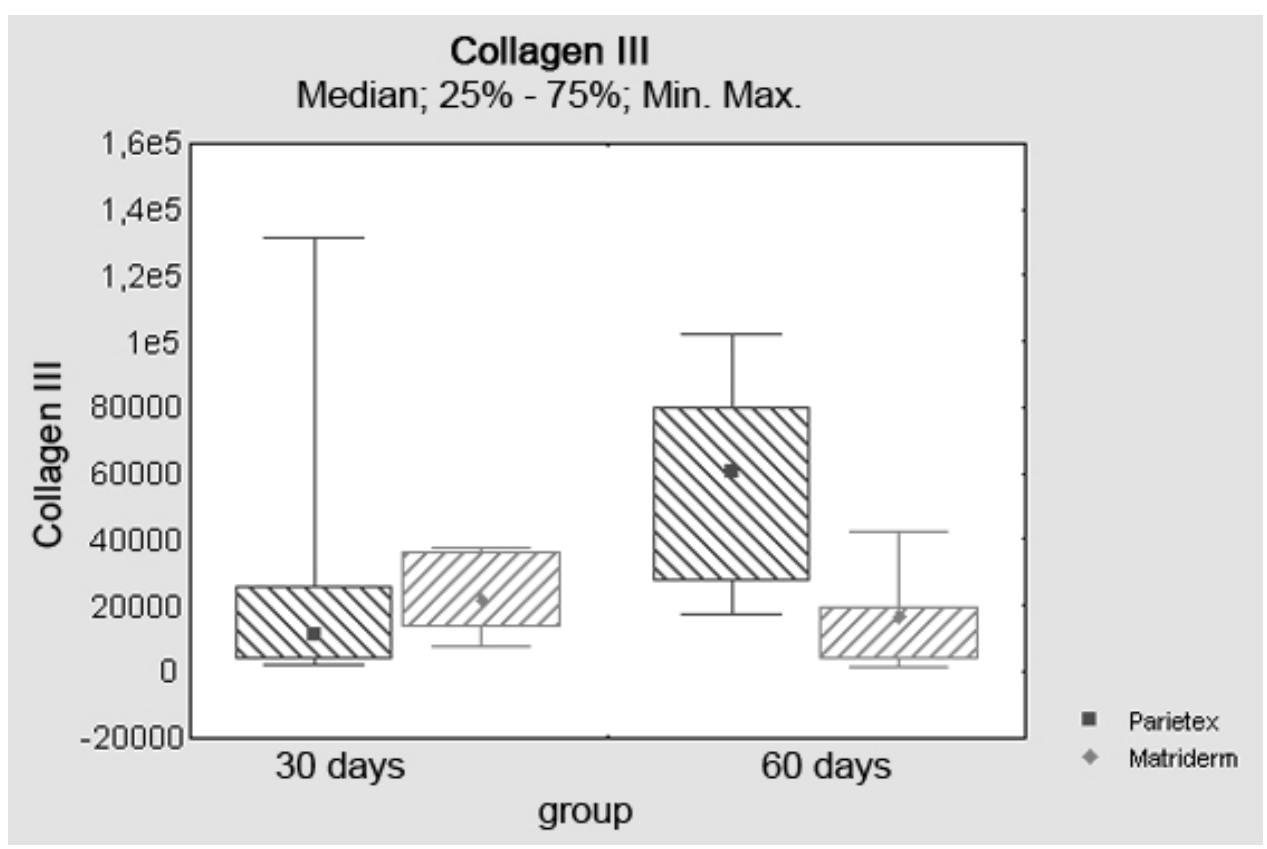

FIGURE 2 - Type III collagen evaluation of the studied meshes 
As to metalloproteinase, there was no statistic significance in the evaluation of MMP-1 and 8.when group A was compared to group B., maintaining the same kind of mesh $(\mathrm{p}=0,022$ for polyester mesh with absorbable film and 0,035 for the collagen-elastin/polypropylene mesh with the increase of its tissue expression from the 30th to the 60th day.

Figures 3 to 5 show these results.

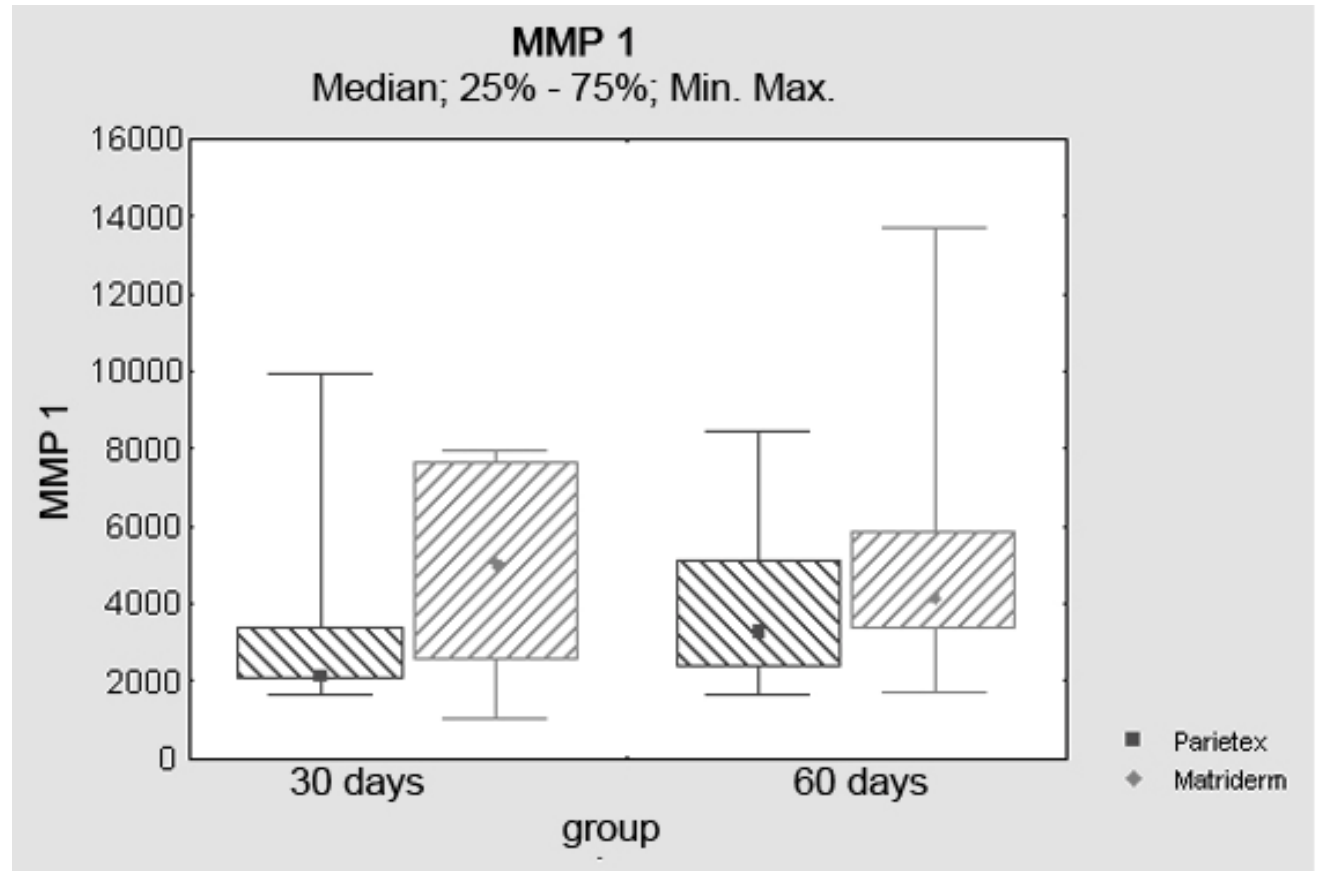

FIGURE 3 - Metalloproteinase 1 evaluation of the studied meshes

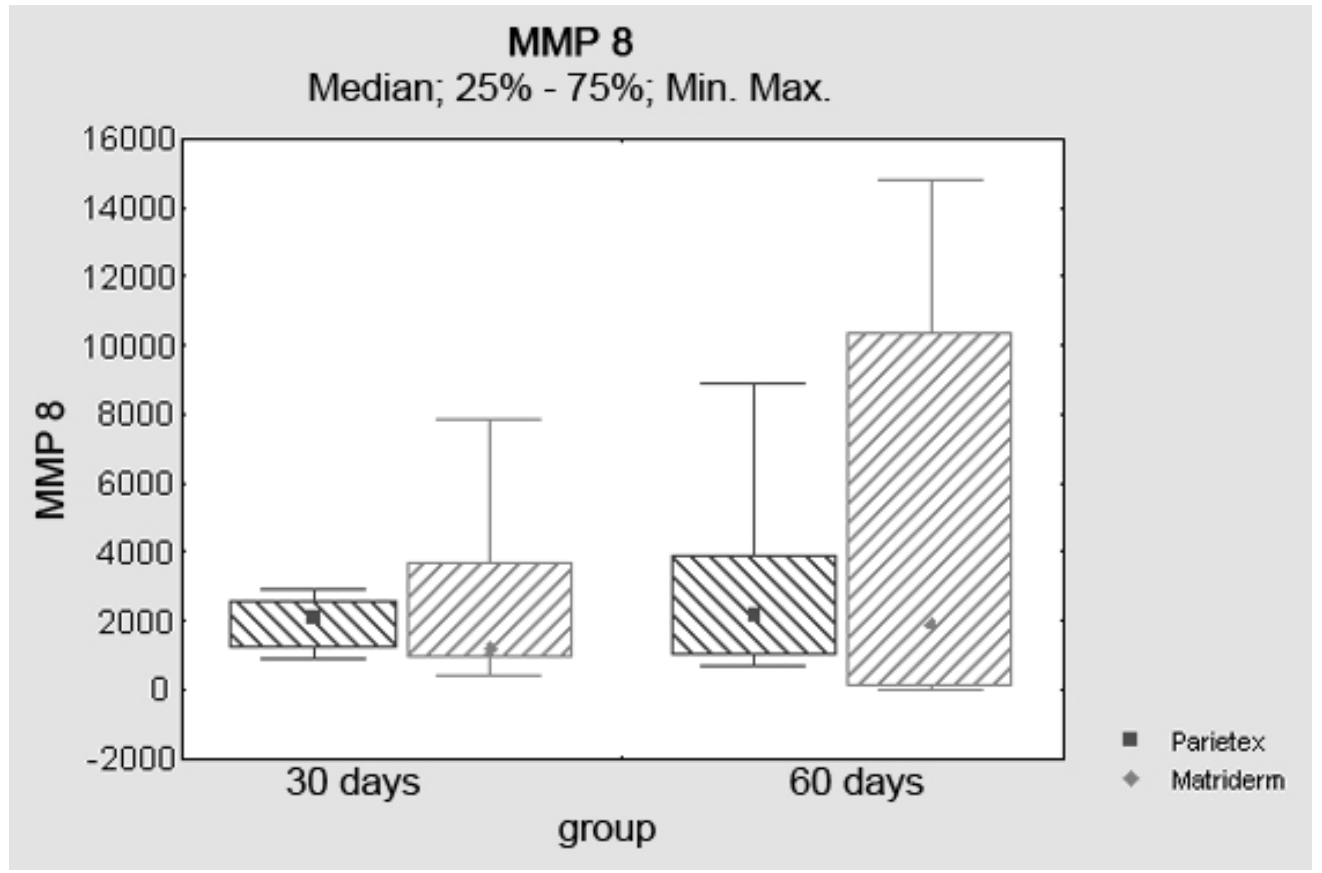

FIGURE 4 - Metalloproteinase 8 evaluation of the studied meshes 


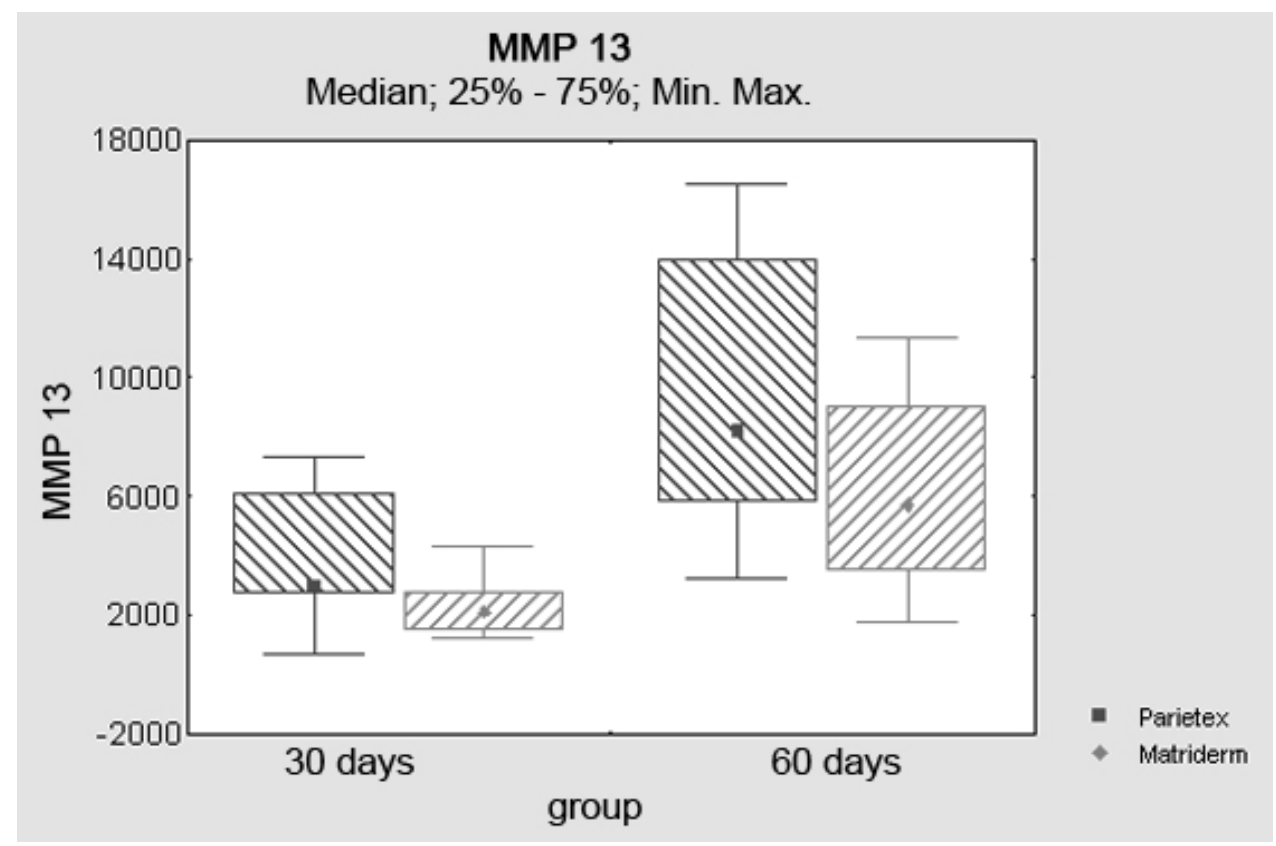

FIGURE 5 - Metalloproteinase 13 evaluation on the studied meshes

\section{Discussion}

The reduction of hernia occurrence on the abdominal wall, after mesh introduction, not only stimulated its use in clinical practice but also stimulated experimental studies in search of a material that would produce less adherence, especially when in visceral contact ${ }^{14,15,16,17}$

The classical tissue reaction to prosthesis placement in the peritoneal cavity is characterized by intense inflammatory response which results in the disordered collagen deposition around the prosthesis and in the interstice of the prosthesis's fibers. Fibroblastic reaction provokes mesh encapsulation that is denser in the peritoneal face when compared to the interposed face with the subcutaneous tissue. An irregular distribution of mesotelial cells, after 4 weeks of mesh implant, would be responsible for adherence formation, especially on the polypropylene mesh, commonly used in the correction of incisional hernias because they are cheaper and easier to manipulate ${ }^{6}$. The macropores of the polypropylene mesh allow fibroblastic growth, giving integrity and resistance to the manipulated tissue, principal cause of the low recurrence of hernias after surgery. However, this advantage is lost when fibroblastic integration becomes responsible for the increase of adherence formation ${ }^{18}$.

Experimental studies indicate that polypropylene's structure and porosity play an important role in adherence formation, in its consistency and, especially in the organization of the neo-peritoneum formed between the mesh and the visceral peritoneum ${ }^{18}$. Even when placed in extra-peritoneal position, the fibrous tissue inside the mesh provokes the contraction of polypropylene prosthesis ${ }^{4}$.

In face of these findings, many mesh compositions for hernia correction have been tested, aiming at combining, at the same time, low adherence formation and the adequate repair of hernial defects. Tetrafluorethylene meshes were presented as the first instrument to solve this problem. One example is the tetrafluorethylene Gore Tex Dual Mesh ${ }^{\circledR}$ that presents, in one of its face, pores smaller than $3 \mu \mathrm{m}$, aiming at reducing adherence formation with the limitation of tissue growth. The opposed face presents pores larger than $100 \mu \mathrm{m}$ which permit the incorporation of the mesh into the tissue. However, there is important evidence of adherence formation in experimental studies that utilized this material ${ }^{2}$, besides the low incorporation of fibroblastic proliferation related to its use which would decrease the tensile resistance of its repair.

Recently, prostheses with a protection layer in one of the meshes' faces have been used in hernia repair. The aim of the protection layer is to form enough space between the mesh and the internal organs while tissue regeneration is under way, without hindering tissue integration to the mesh. In rats and rabbits, a hyaluronate carboxymethyl cellulose membrane was tested to decrease adherence formation ${ }^{3,4}$. Another feasible option amply used nowadays is the Polyester mesh with absorbable film made of polyester and a hydrophilic absorbable film in its visceral face. This film is made of bovine type 1 collagen, polyetilene glicol and glycerol. This film is completely absorbed within two weeks and a new peritoneum is already formed, covering the mesh. However, Van t Riet's study ${ }^{18}$ using polyester with absorbable film showed that there was an intense inflammatory response and greater predisposition to infection which probably contributed to an increase in the incidence of adherences and enterocutaneous fistulas (16\%). Experimental studies have shown favorable perspectives for their use besides combining minimum adherence formation, good mesh incorporation and resistence ${ }^{20}$.

The second mesh selected for this present study is a composition of polypropylene sutured to collagen-elastin. The collagen-elastin mesh is a tri-dimensional matrix composed of native collagen fibers, structurally intact and elastin, developed to bear dermal regeneration. Its collagen is obtained from bovine dermis and contains dermal type I, II, III and IV collagen. Elastin is obtained from bovine nuchal ligament by hydrolysis. Its use 
helps skin reconstitution and regulates the formation of cicatricial tissue. It has excellent hemostatic properties and reduces hematoma formation bellow the grafts.

Its main indication is dermal reconstruction and the total thickness defects combined with grafts of autologous mesh in the treatment of burnt patients and in plastic surgery.

Collagen-elastin is an acellular tissue substitute. Collagen structure serves as a matrix for cell migration and proliferation and for vascularization. Collagen elastin thickness permits the initial supply of the graft by way of diffusion and quick vascularization. With the advance of the cicatrization process, fibroblasts produce their own collagen while the matrix is degraded.

Due to the attributes above mentioned, collagen-elastin was selected in this study to work as an interface between the visceral contents of the abdominal cavity and the polypropylene mesh.

In this study, the major part of adherences was loose (Nair's 0 and 1) and there was no difference in adherence formation between the polyester with absorbable film mesh and the collagen-elastin/polypropylene mesh.

However, literature does not mention studies of the use of collagen-elastin/polypropylene in the correction of incisional hernias. In the review of the literature on the subject, we found mentions of animal experiments using similar material ${ }^{20}$. The composition of such material is the one of a dermal matrix processed from the skin of human corpses. This material also undergoes a process of preparation with the removal of dermal cells with sodium-deoxycholate until the formation of ice crystals. The final product contains collagen, elastin and laminine from human dermis ${ }^{20}$.

A study of ventral hernia repair in rabbits a quick graft vascularization and tissue resistance was detected, similar to the use of polytetrafluoretilene mesh, after four weeks of the implant ${ }^{12}$.

There are studies in which collagen-elastin is used in the regeneration of joint cartilage ${ }^{20}$. The low capacity of joint cartilage auto-repair after a lesion is well known. In these studies, chondrocytes are scattered on collagen 1 matrix and elastin, demonstrating high viability besides stimulating type II collagen formation, as certified by immunohistochemical analysis and type II collagen gene expression ${ }^{20}$.

For this reason, we made the present study of collagenelastin/polypropylene using the immunohistochemical analysis and collagen research and then compared it with the tissue response of the Polyester mesh with absorbable film.

The immunohistochemical analysis of the meshes was conducted with the analysis of three metalloproteinases - MP-1, 8 and 13. There are approximately 20 Matrix-Metalloproteinase MMPs). They belong to different classes, among them Collagenases (MMP - 1, 8, 13) gelatinases (MMp - 2 and 9), stromelisines (MMP 3 and 10), matrilisines MMP-7), membrane MMPs (14 and 16) and others (MMP - 12 and 20).

In a healthy organism, the liberation of proteolytic enzymes is circumscribed and controlled by enzymatic inhibitors that favor the resolution process of physiological tissue damage ${ }^{4}$.With MMP 1, 8 and 13 colagenases involved in collagen catabolism were evaluated as well as the collagenases directly involved with types I and III collagen synthesis. These collagenases degrade the molecules of interstitial type I and III collagens, besides digesting other molecules of the extra-cellular matrix.
However, there are not only differences among these collagenases but also on the tissue expression of each one of them, depending on the condition of the cicatrization process. Thus, when MMP-1 expression is increased, there is a delay on the cicatrization process. However, MMP-8 significantly increases chronic processes of cicatrization which cause marked proteolysis and the inactivation of wound growth factors. MMP-13 is related to chronic wounds, when cicatrization is altered in medium term. With this information, one can say that an increase in tissue expression of Matrix Metalloproteinases entails a delay or compromises the process of cicatrization. This study points out to the increase in metalloproteinases on the second observation period (60 days), simultaneously with a decrease of type I collagen concentration, probably due to the increase of these enzymes' activity and the remodeling of the tissue formed on the mesh.

Studies of the influence of MMP-1 and MMp-2 metalloproteinases in patients with incisional hernias, samples of the patients' fascia who underwent incisional hernia repair and of patients who did no present hernias and were submitted to a second laparotomy were obtained during surgery and analyzed with Western Blot and polymerase reaction (PCR) to determine types I, II and III collagen and MMPs- 1 and $2^{20}$. The relation collagen I and III was low in patients with incisional hernias. MMP-1 did not differ in both groups; however, MMP- 2 was significantly elevated in patients with incisional hernias. It was concluded that the reduction of the rates ColageI/III and MMP -1/MMP 2 could be the explanation to the development of incisional hernias and MMP-2 inhibitors could be potential subject $\mathrm{s}$ for the study for incisional hernia prevention.

The studies consulted show greater collagen concentration in absorbable meshes such as polyglactin ${ }^{26}$ and low collagen concentration in polytetrafluoretilane meshes when compared to polypropylene meshes. In this present study, there is greater collagen concentration in the polyester mesh with absorbable film on the 30th day after surgery, with statistical difference in relation to the collagen-elastin/polypropylene mesh. This concentration decreases with the passing of time, becoming again significant in the polyester with absorbable film group. One can speculate that the greater collagen concentration on the polyester mesh with absorbable film may be due to the collagen layer of its visceral face, although the collagen elastin/polypropylene face is also composed of type I collagen. With the passing of time, this collagen is reabsorbed and the tissue is remodeled, causing the decrease of its concentration. Although the collagen-elastin/ polypropylene mesh is not significant, it also presented a greater collagen concentration in the first observation period. Type III collagen is more concentrated on the Polyester with absorbable film mesh than on the collagen-elastin/polypropylene mesh. This concentration decreases with the passing of time.

The formation of disorganized conjunctive tissue may be associated to adherence formation and alterations on mesh integration, certified by immumohistochemestry ${ }^{28}$. Immunohistochemical analysis of this study showed an increasing tendency of metalloproteinases MMP -8 and 13, related to the delay in cicatrization. Statistical analysis was significant only for MMP- 13 in the evaluation of the same mesh in separate periods of observation. Thus, based on immunohistochemistry, there is no differentiation between them. 


\section{Conclusions}

1. There is no significant difference between the meshes in adherence formation in the peritoneal cavity;

2. In the picrosirius staining evaluation of collagen formation, the polyester mesh with absorbable film presented a greater concentration of types I and III collagen than the collagenelastin/polypropylene mesh; however, this concentration varied according to the evaluated period after surgery;

3. MMP -13 was the only metalloproteinase that presented a significant increase in its immunoexpression, when the same mesh is evaluated in different periods of observation because there is no significant difference between the meshes.

\section{References}

1. Christoforoni PM, Kim YB, Preys Z, Lay RY, Montz FJ. Adhesion formation after incisional hernia repair: a randomized porcine trial. Am Surg. 1996;62(11):935-8.

2. Gonzalez R, Rodeheaver GT, Moody DL, Foresman PA, Ramshaw BJ. Resistance to adhesion formation: a comparative study of treated and untreated mesh products placed in the abdominal cavity. Hernia. 2004;8(3):213-9.

3. Alimoglu O, Akcakaya A, Sahin M, Unlu Y, Ozkan OV, Sanli E, Eryilmaz R. Prevention of adhesion formations following repair of abdominal wall defects with prosthetic materials (an experimental study). Hepatogastroenterology. 2003;50(51):725-8.

4. Salameh JR, Talbott LM, May W, Parminder JS, McDaniel DO. Role of biomarkers in incisional hernias. Am Surg. 2007;73(6):561-8.

5. Greenawalt KE, Butler TJ, Rowe EA, Finneral AC, Garlick DS, Burns JW. Evaluation of sepramesh biosurgical composite in a rabbit hernia repair model. J Surg Res. 2000;94(2):92-8.

6. Law NW. A comparison of polypropylene mesh, expanded polytetrafluoroethylene patch and polyglycolic acid mesh for the repair of experimental abdominal wall defects. Acta Chir Scand. 1990;156(11-12):759-62.

7. Ammaturo C, Bassi G. Surgical treatment of large incisional hernias with an intraperitoneal Parietex Composite mesh: our preliminary experience on 26 cases. Hernia. 2004;8(3):242-6.

8. Jenkins SD, Klamer TW, Parteka JJ, Condon RE. A comparison of prosthetic materials used to repair abdominal wall defects. Surgery. 1983;94(2):392-8.

9. Bellón JM, Hernando A, Contreras L. Importance of the peritoneal interface following implantation of biomaterials into the abdominal wall. Br J Surg. 1994;81(Suppl 1):69.
10. Becker JM, Dayton MT, Fazio VW, Beck DE, Stryker SJ, Wexner SD, Wolff BG, Roberts PL, Smith LE, Sweeney SA, Moore M. Prevention of postoperative abdominal adhesions by a sodium hyaluronate-based bioresorbable membrane: a prospective, randomized, double-blind multicenter study. J Am Coll Surg. 1996;183(4):297-306.

11. Hooker GD, Taylor BM, Driman DK. Prevention of adhesion formation with use of sodium hyaluronate-based bioresorbable membrane in a rat model of ventral hernia repair with polypropylene mesh: a randomized, controlled study. Surgery. 1999;125(2):211-6.

12. Menon NG, Rodriguez ED, Byrnes CK, Girotto JA, Goldberg NH, Silverman RP. Revascularization of human acellular dermis in full-thickness abdominal wall reconstruction in the rabbit model. Ann Plast Surg. 2003;50(5):523-7.

13. Nair SK, Bhat IK, Aurora AL. Role of proteolytic enzyme in the prevention of postoperative intraperitoneal adhesions. Arch Surg. 1974;108(6):849-53.

14. Dabrowiecki S, Svanes K, Lekven J, Grong K. Tissue reaction to polypropylene mesh: a study of oedema, blood flow, and inflammation in the abdominal wall. Eur Surg Res. 1991;23(3-4):240-9.

15. James NL, Poole-Warren LA, Schindhelm K, Milthorpe BK, Mitchell RM, Mitchell RE, Howlett CR. Comparative evaluation of treated bovine pericardium as a xenograft for hernia repair. Biomaterials. 1991;12(9):801-9.

16. Bellón JM, Contreras LA, Buján J, Carrera-San Martín A. The use of biomaterials in the repair of abdominal wall defects: a comparative study between polypropylene meshes (Marlex) and a new polytetrafluoroethylene prosthesis (Dual Mesh). J Biomater Appl. 1997;12(2):121-35.

17. Kaleya RN. Evaluation of implant/host tissue interactions following intraperitoneal implantation of porcine dermal collagen prosthesis in the rat. Hernia. 2005;9(3):269-76.

18. van 't Riet M, de Vos van Steenwijk PJ, Bonthuis F, Marquet RL, Steyerberg EW, Jeekel J, Bonjer HJ. Prevention of adhesion to prosthetic mesh: comparison of different barriers using an incisional hernia model. Ann Surg. 2003;237(1):123-8.

19. Bellón JM, García-Carranza A, Jurado F, García-Honduvilla N, Carrera-San Martin A, Buján J. Peritoneal regeneration after implant of a composite prosthesis in the abdominal wall. World J Surg. 2001;25(2):147-52. 20. Burger JW, Halm JA, Wijsmuller AR, ten Raa S, Jeekel J. Evaluation of new prosthetic meshes for ventral hernia repair. Surg Endosc. 2006;20(8):1320-5.

\section{Acknowledgement}

To the University of Würzburg for the cooperative trial with German meshes.

\section{Correspondence:}

Conflict of interest: none Financial source: none

Danielle Duck Schulz

Al. Augusto Stellfeld, 1980

80730-150 Curitiba - PR Brazil

Phone: (55 41)3240-5488

ipem@evangelico.org.br

Received: April 08, 2009

Review: June 12, 2009

Accepted: July 25, 2009

\section{How to cite this article}

Schulz DD, Czeczko NG, Malafaia O, Schulz GJ, Czeczko LEA, Garcia LS, Dietz UA. Evaluation of healing prosthetic materials polyester mesh resorbable film and collagen elastin matrix /polypropylene used in rabbits abdominal wall defects. Acta Cir Bras. [serial on the Internet] 2009 Nov-Dec;24(6). Available from URL: http://www.scielo.br/acb 